\title{
Consumer Price Indexes: An Analysis of Heterogeneity Across Sub-Populations
}

\author{
Raffaele Santioni, Isabella Carbonaro, and Margherita Carlucci
}

\section{Introduction}

The soundness of Consumer Price Index (CPI) as a measure of inflation has long been debated, focusing on the different sources of bias inherent to the use of a constant basket of goods and services. ${ }^{1}$ At the end of the twentieth century the Boskin Commission's report (Boskin, Dulberger, Gordon, Griliches, \& Jorgenson, 1996) showed an overstatement of $1.1 \%$ per year from CPI data, mainly due to substitution bias and inadequate treatment of quality changes. On the contrary, following the euro cash changeover in 2002, evidence of wide gaps between consumers' perceptions and official measures of inflation was found in many countries of the euro area $^{2}$ showing understatements of more than $3.5 \%$ per year from CPI data in 2003.

The gap between perceived and official inflation could lead to serious consequences for economic policy: erosion of the euro's public acceptance and its institutional framework (Del Giovane \& Sabbatini, 2006), distorted inflation expectations influencing prices and wages; and even questioning the credibility of monetary policy (Brachinger, 2006).

According to literature, there are many possible explanations for this gap.

Basically, official measures of inflation rate follow a methodology established at international level, based on a subset of actual final consumption of resident households, derived from national accounts statistics. So the index is not representative

\footnotetext{
R. Santioni $(\bowtie)$

Bank of Italy, Economic Research Unit, Rome, Italy

e-mail: raffaele.santioni@bancaditalia.it

${ }^{1}$ This research was funded by PRIN 2005. The Authors thank Martino Lo Cascio and the participants in the International Workshop on Price Index Numbers in Time and Space, held in Florence, September 29th 2008, for useful comments. The views expressed in this paper are those of the authors and do not involve the responsibility of the Bank of Italy.

${ }^{2}$ See, for instance, ECB (2007), Jungermann, Brachinger, Belting, Grinberg, and Zacharias (2007) for Germany; Kurri (2006) for Finland; Fluch and Stix (2005) for Austria; Álvarez González et al. (2004) for Spain; Del Giovane and Sabbatini (2006) and Del Giovane, Fabiani, \& Sabbatini (2008) for Italy. Assessment of perceived inflation derives from qualitative opinion surveys, such as European Commission's Consumer Survey.
} 
of a particular social group but of the community. Otherwise, inflation perceived by consumers appears conditioned by the individual patterns of consumption, and also by subjective factors, such as asymmetries in the perception of price movements upwards and downwards.

CPI can only be an average of differentiated price increases of individual products and in different territories. Therefore the index, summarizing the spending behavior of all households, might not match the inflation rate experienced by each individual family as a result of its specific consumption basket.

Thus experimental consumer price indexes have been proposed for targeted subpopulations specifically relevant for social and economic policy, that are likely to have consumption patterns different from the average, i.e. poor (Garner, Johnson, \& Kokoski, 1996) and elderly (Stewart, 2008) households. Experimental indexes are a reweighting of the CPI elementary indexes using expenditure weights from households belonging to the sub-population of interest (BLS, 1997).

Moreover, the goods and services whose prices enter in CPI do not include items relevant in family expenditures that are not considered as consumption but as family's investment or inter-institutions transfers. The first is the case of house prices, not covered in the domain of consumer prices, but whose increase substantially affects the perceived loss of purchasing power among lower-income households (Ranyard, Missier, Bonini, Duxbury, \& Summers, 2008). The second is the case of insurance premiums, valued in CPI net of claims and surrenders: thus increases in their prices enter the index with weights much smaller than their actual burden on family's expenditures.

On the other hand, due to asymmetry in perceptions, consumers seem to form their idea of general inflation on the basis of a smaller commodity basket than that of the CPI. Price increases in items with high purchase frequency and out-of-pocket payment, like food, petrol, coffee services and hairdressing, count much more than price reductions in infrequently purchased items, paid for with credit card or via automatic bank transfer, like home electronics.

Speculative behavior of price setters in "grey zones" (Wunder, Schwarze, Krug, \& Herzog, 2008): non-competitive markets of the service sector, such as restaurants (Adriani, Marini, \& Scaramozzino, 2009), cinema tickets and dry cleaning, more influential costs of the adjustment to the new currency for items paid for in cash, varying accuracy of consumers' memory of prices, may also play a role.

These findings suggest that an "out-of-pocket" subsample of CPI basket could provide an index better suited to catch perceived inflation rate of growth (Lyziak, 2009; ECB, 2003; contrasting findings are reported in Antonides, 2008).

Aim of this work is to investigate the possibilities offered by alternative methods of construction of consumer price indices in order to capture the variability of inflation rates facing different households' types.

\section{Definition of Experimental Price Indexes}

CPI measures the changes in the price of a fixed basket of goods and services purchased by an average - or representative - consumer. The increase in prices which 
individual households actually faces is, however, a phenomenon depending on the specific family's consumption profile.

In fact, factors contributing to erosion of real purchasing power of a given amount of spending can be attributed to two main sources of heterogeneity (Schultze \& Mackie, 2002):

1. Households differently allocate their budget spending in various categories of goods and services, with consumer spending patterns mainly related to households' profile. These typical differences in the allocation of budget shares, or across-strata heterogeneity, are the rationale behind the construction of BLS experimental indexes based on specific weighting systems;

2. Households' consumption patterns differ not only in expenditure budget shares, but also in retail outlets and consumption items actually purchased. This one is called within-stratum heterogeneity. If the hypothesis that all families face the same set of retail place is to be dismissed, and if there are reasons to believe that the elderly or the poor face higher prices, these groups could suffer more rapid inflation rates than the entire population (Rao, 2000).

Official statistics' data only allow to control for differences in spending patterns across households, since Household Budget Surveys (HBS) currently provide detailed data on family expenditures' shares, while price quotes by outlet and items are not published. Thus, official data do not allow estimates of price dispersion ${ }^{3}$ faced by different households.

Following Pollak (1998), another way to look at heterogeneity involves answering three questions: "How many indices?"; "Beer or champagne?"; and "What type of group indices?". The first one refers to heterogeneity in households' consumption patterns, calling for different indexes for population subgroups (across-strata heterogeneity). The second one raises the problem of appropriate selection of items and outlets included in the inflation index (within-stratum). The third one introduces an issue not yet analyzed.

CPI is a weighted average of products' price indices, with weights given by their respective shares in aggregate consumption expenditure. Assuming that all households face the same lower-level price indexes, this means that each household receives a weight in accordance to its total expenditure. Since expenditure increases with income, this approach (the so-called plutocratic approach) gives greater influence to the consumption patterns of rich households than to poor ones. Thus, since the families who spend more contribute more to national expenditure shares compared to less affluent ones, the wealthiest families have a greater say in determining CPI value (the "one dollar one vote" criterion). Empirical evidence shows that the ideal "average" consumer of CPI is rather a rich one. For the United States in 1990,

\footnotetext{
${ }^{3}$ It is worthwhile noting that this kind of price heterogeneity also affects CPI via formulas used for calculating elementary indexes, since the use of geometric (as in Italy and several other countries) or arithmetic unweighted means of prices' ratios lead to different values depending on the variances of the logarithms of sampled prices (Silver \& Heravi, 2007).
} 
Deaton (1998) located this consumer in the 75 percentile of the distribution of consumption expenditure; for Spain during the 1990s Izquierdo, Ley, and Ruiz-Castillo (2003) in the 61 percentile, while household data from four Latin American countries (Brazil, Colombia, Mexico, and Peru) in a period spanning from 1984 to 2003 showed that standard CPI weights typically reflect those of a consumer located in the 80-90 percentile (Goni, Lopez, \& Servén, 2006).

On the contrary, if we decide to accord equal weight to each household, the aggregate price index follows the democratic formula (the "one household one vote" criterion).

One reason for official statistics to prefer plutocratic indexes (Kokoski, 2003) lies in that only information on prices and aggregated expenditure shares are needed, while for a democratic index one must first construct the price index for each individual household, then average them to produce an aggregate index.

To show the differences between plutocratic and democratic formulas, we define the Laspeyres price index ${ }^{h} L_{t-1}^{t}$ for each individual household, $h$, as follows:

$$
{ }^{h} L_{t-1}^{t}=\sum_{i=1}^{n}\left(\frac{p_{i, t}}{p_{i, t-1}}\right){ }^{h} s_{i, t-1}=\sum_{i=1}^{n} P_{i, t-1}^{t}{ }^{h} s_{i, t-1}
$$

where ${ }^{h} s_{i, t-1}$ is the product $i$ 's share of household $h$ 's total expenditure in the base period $t-1$ and $P_{i, t-1}^{t}$ is product $i$ 's elementary price index. The aggregate price index for all $H$ households could be expressed by:

$$
{ }^{H} L_{t-1}^{t}=\sum_{h \in H}{ }^{h} w_{t-1}{ }^{h} L_{t-1}^{t}=\sum_{h \in H}{ }^{h} w_{t-1} \sum_{i=1}^{n} P_{i, t-1}^{t}{ }^{h} s_{i, t-1}
$$

where ${ }^{h} w_{t-1}$ is the weight given to household $h$ in the aggregate index.

In the democratic approach each household $h$ counts with the same weight $h_{w_{t-1}}=1 / H$ and the corresponding index is the unweighted arithmetic mean of the $H$ individuals households' price indexes.

$$
{ }_{d}^{H} L_{t-1}^{t}=\frac{1}{H} \sum_{h \in H}{ }^{h} L_{t-1}^{t}=\frac{1}{H} \sum_{h \in H} \sum_{i=1}^{n} P_{i, t-1}^{t} h_{S_{i, t-1}}
$$

In the plutocratic approach weights are proportional to each household's total expenditure ${ }^{h} E_{t-1}$ at the base period,

$$
h_{w_{t-1}}=\frac{{ }^{h} E_{t-1}}{\sum_{h \in H}{ }^{h} E_{t-1}}
$$


The corresponding index equals to:

$$
{ }_{p}^{H} L_{t-1}^{t}=\sum_{h \in H}{ }^{h} L_{t-1}^{t} \frac{{ }^{h} E_{t-1}}{\sum_{h \in H}{ }^{h} E_{t-1}}=\sum_{h \in H} \sum_{i=1}^{n} P_{i, t-1}^{t} \frac{{ }^{h} p_{i, t-1}{ }^{h} q_{i, t-1}}{{ }^{H} E_{t-1}}
$$

It is straightforward to show that ${ }_{p}^{H} L_{t-1}^{t}$ is the current CPI index.

Due to the combined effect of differences in consumption patterns across individual households (i.e. rich households buying luxuries and poor ones buying necessities) and in inflation rates across goods (i.e. with luxury goods or necessities experiencing higher than average inflation), the two approaches lead to different estimates of overall inflation rates. The gap ${ }^{4}$ between inflation measured according to CPI and according to a democratic index is called plutocratic bias. Depending on whether prices behave in an anti-rich or an anti-poor manner the bias will be positive or negative. In any case, the more different family consumption patterns are, the less CPI could represent inflation rate suffered by poorer households.

Therefore, the use of a single price index to adjust the income of a collectivity has a redistributive effect. Individuals whose price index variations are lower than those experienced by the official index used to deflate nominal income receive an unexpected benefit, as opposed to those who face inflation rates higher than "average" one, which in fact suffer a net loss. As a result, it is desirable to use specific price indices for subgroups of the population when analyzing time changes of households' purchasing power and inequality. ${ }^{5}$ Some attempts have already been performed in Italy (ISTAT, 2007), even if there are many conceptual and operational drawbacks (Biggeri \& Leoni, 2003).

In this study we used ISTAT Households Budget Survey (HBS) data for the years 1999-2005 and ISTAT monthly price indexes (CPI) by representative positions for 2000-2006.

We first developed sub-indexes breaking down Italian families' by equivalised expenditure decile. Then, we focused our attention on selected households that are likely both to have specific consumption behavior and to be particularly sensitive to the loss of purchasing power:

- single person with dependent children;

- head of family workless through unemployment or economic inactivity;

- elderly.

\footnotetext{
${ }^{4}$ It is worthwhile noting that the assumption of identical lower-level price indexes may lead to substantial underestimation of this gap (Izquierdo et al., 2003; Kokoski, 2003).

${ }^{5}$ The impact on inequality depends on how much households' expenditure profiles differ across income-groups (see Son \& Kakwani, 2006).
} 
To control ${ }^{6}$ for across-strata heterogeneity we constructed sub-indexes defined applying to lower-level price indexes specific family types' weights according to their expenditures patterns resulting from HBS.

We also checked the effect of changes in the sample of goods and services, developing a Laspeyres price index for a basket of frequently purchased goods and services, defined on the basis of empirical evidence provided by previous studies (Carlucci \& Zelli, 1998) as common "Necessities" of any type of households, regardless the phase of family life cycle they are within, related to daily basic personal needs and housing maintenance. This reference basket includes food and non-alcoholic beverages, electricity and household fuels, household cleaning products, communication charges.

\section{Data}

\subsection{Harmonisation of HBS and CPI Data}

To build up weights for sub-populations we used HBS micro data on family characteristics and expenditures, broken down in nearly 300 categories (corresponding to five-digit level Classification Of Individual COnsumption by Purpose, COICOP-HBS) for the years 1999-2005.

These data are not fully correspondent to CPI requirements either in coverage or in classification criteria. CPI measures the changes over time in the prices of a basket of goods and services representative of all those purchased for final consumption of household. It means that CPI does not include investment items, compensative and non-monetary transactions, recorded as families' expenditures in HBS. Thus we firstly had to remove HBS headings such as mortgages, life insurances, repayments of loans and outlays, services engaged for major maintenance and repairs or for extensions and conversions of dwellings (capital formation), purchases of second-hand vehicles (compensative) and imputed rentals of owneroccupied houses (non-monetary). We also removed expenditures on game of chance and expenditures abroad, not covered in the CPI sample.

Merging the remaining HBS expenditures and CPI price indexes is not a straightforward operation, since the headings of the two sources do not always coincide. In building the transition matrix to match CPI indexes to HBS categories, we had to copy with the fact that HBS commodity headings are not only more aggregated than CPI representative positions but also follow different grouping criteria than the ones used for CPI. We operated at the most disaggregated level we could, namely at the voice of product's level. Only when it was not possible we matched headings

\footnotetext{
${ }^{6}$ With the caveat that weights used for sub-groups derive from sub-samples of HBS whose size may affect estimates' precision (BLS, 1997).
} 
at group of product's level. ${ }^{7}$ In few cases the HBS heading corresponded to different CPI levels, so we matched CPI of representative positions with voices of product' ones to cover the HBS definition. ${ }^{8}$ In the end, we defined a one-to-one match between about $280 \mathrm{HBS}$ expenditure items and 155 consumer price indexes, exhausting the entire reference domain of CPI listing.

\subsection{Weights' Identification}

Expenditures of each household in the HBS samples have been broken down in the 155 groups for which we have matched CPI elementary price indexes. For household $h$ we computed the vector of weights at time $t, t=1999, \ldots, 2005$, namely ${ }^{h} s_{t}=$ $\left({ }^{h} s_{1, t},{ }^{h} s_{2, t}, \ldots,{ }^{h} s_{155, t}\right)$, where ${ }^{h} s_{i, t}=\frac{{ }^{h} E_{i, t}}{\sum_{i=1}^{155}{ }^{h} E_{i, t}},{ }^{h} E_{i, t}$ is the expenditure for the group $i$, $i=1,2, \ldots, 155$, and $\sum_{i=1}^{155}{ }^{h} E_{i, t}$ total expenditure. ${ }^{9}$

It is worthwhile noting that even if National Accounts (NA) estimates of consumption - that provide weights for official CPI - heavily rely on HBS data, the two sources lead to different values, specially for selected items, such as items that are purchased at a frequency lower than one month. However, we may assume that, in terms of quality and reliability, the weighting coefficients obtained from the HBS represent a good approximation of NA ones and therefore can be used for the transition from a structure of common weights for all family types to a set of weights for subgroups.

Hence, we evaluated monthly (calculation base) consumer price indexes for each $h$-th family as:

$$
{ }_{c b}^{h} L^{m, t}=\sum_{i=1}^{155}{ }^{12, t-1} P_{i}^{m, t} h_{s_{i, t-1}} \quad h, m=1, \ldots, 12 \text { and } t=2000, \ldots, 2006
$$

where ${ }^{12, t-1} P_{i}^{m, t}$ is the national price index of the $i$-th group between month $m$ of year $t$ and December of the year $t-1$ (calculation base), as published by ISTAT.

\footnotetext{
${ }^{7}$ This means that in these cases our lower-level price ratios are themselves price indexes (see Hill, 2004) but at this level of detail we are fairly confident that this should not have important effects on our final results.

${ }^{8}$ For instance, to match the HBS heading "Bread and other bakery products" we had to aggregate the index of group of products "Bread" with the indexes of the two representative positions "Crackers" and "Bread sticks".

${ }^{9}$ Total expenditure here refers only to the HBS expenditures covered by CPI domain of observation (see Sect. 3.1).
} 
Chained indexes (reference base December 1999) have finally been calculated by

$$
{ }_{r b}^{h} L^{m, t}=\prod_{k=2000}^{t-1} \frac{{ }^{h} L^{12, k}}{100}{ }_{c b}^{h} L^{m, t} \quad h, m=1, \ldots, 12 \text { and } t=2000, \ldots, 2006
$$

\subsection{Identification of Sub-Groups}

For ethical and thence policy aims, the most important issue to investigate is to what extent poorer families are liable to suffer inflation rates higher than average. In this context, families' wellbeing can be measured in terms of the amount of goods and services for households' consumption. Thus, economic condition for each family has been defined in terms of its HBS expenditures, excluding only those which are not included in consumption, as contributing to capital formation (see above, Sect. 3.1). Since we wanted a proxy for economic welfare, we considered also non monetary flows that accrue the amount of available goods and services, such as services of owner-occupied dwellings, measured as imputed rentals.

We applied the concept of equivalent total consumption expenditure of the family in order to compare families of different size. It has been determined by dividing total expenditure of the family for appropriate deflators, the so-called equivalence scales, that take into account the economies of scale in family consumption. In literature different equivalence scales have been proposed, without a general consensus about which one to use in the different situations. Since the choice could affect the results, ${ }^{10}$ we decided to use the official scale used in Italy by ISTAT to assess poverty, the Carbonaro's scale (1985).

We have therefore separated households into deciles of the distribution of equivalent total consumption expenditure, with decile 1 comprising the poorest ${ }^{11} 10 \%$ of the households, decile 10 the richest $10 \%$ and so on. The thresholds used for the different years are given below, Table 1 .

In addition to select population's subgroups on the basis of equivalent expenditure deciles, other types of families were taken into consideration based on the characteristics of household's members (relationship with the reference person, age, occupation). As noted before (see Sect. 2), these family types are as follows:

- single person with dependent children (less than 18 years old);

- head of the family workless through unemployment or economic inactivity ${ }^{12}$;

\footnotetext{
${ }^{10}$ For instance, Engel's equivalence scales measured with food share could overestimate the needs of large families, while Rothbarth's ones may underestimate the needs of families with children (see Carlucci \& Zelli, 1998).

11 "Poorest" and "richest" refer to our definition of wellbeing in terms of goods and services available for consumption.

${ }^{12}$ Excluding unemployed single person with dependent children.
} 
Table 1 Equivalent expenditure deciles: lower boundary of groups (current euro)

\begin{tabular}{llllllllll}
\hline Year & $\begin{array}{l}\text { Second } \\
\text { decile }\end{array}$ & $\begin{array}{l}\text { Third } \\
\text { decile }\end{array}$ & $\begin{array}{l}\text { Fourth } \\
\text { decile }\end{array}$ & $\begin{array}{l}\text { Fifth } \\
\text { decile }\end{array}$ & $\begin{array}{l}\text { Sixth } \\
\text { decile }\end{array}$ & $\begin{array}{l}\text { Seventh } \\
\text { decile }\end{array}$ & $\begin{array}{l}\text { Eighth } \\
\text { decile }\end{array}$ & $\begin{array}{l}\text { Ninth } \\
\text { decile }\end{array}$ & $\begin{array}{l}\text { Highest } \\
10 \%\end{array}$ \\
\hline 1999 & 431.33 & 558.22 & 661.48 & 763.15 & 880.03 & 1106.50 & 1171.28 & 1407.38 & 1858.50 \\
2000 & 451.06 & 574.61 & 685.46 & 796.43 & 915.15 & 1052.44 & 1233.39 & 1487.99 & 1990.37 \\
2001 & 460.45 & 584.20 & 693.66 & 805.13 & 917.93 & 1067.95 & 1254.07 & 1516.27 & 1998.48 \\
2002 & 477.07 & 603.92 & 713.60 & 825.85 & 950.78 & 1093.81 & 1267.46 & 1512.90 & 1979.53 \\
2003 & 510.68 & 643.20 & 757.59 & 875.17 & 1003.92 & 1154.36 & 1343.60 & 1611.66 & 2113.61 \\
2004 & 521.50 & 666.03 & 791.98 & 918.58 & 1058.45 & 1222.22 & 1424.44 & 1709.52 & 2234.62 \\
2005 & 541.82 & 686.49 & 816.18 & 950.26 & 1087.28 & 1248.31 & 1446.60 & 1744.88 & 2234.01 \\
\hline
\end{tabular}

- head of the family retired;

- elderly, regardless their occupational status.

These groups of households are characterized by substantial differences, as can easily be seen in Table 2, derived from HB Survey for the year 2005.

Data for the year 2005 support our choice of these families as the most sensitive to the risk of poverty.

Table 2 Characteristics of households by sub-group (HBS, 2005)

\begin{tabular}{|c|c|c|c|c|c|}
\hline Household & $\begin{array}{l}\text { Average } \\
\text { monthly } \\
\text { household } \\
\text { expenditure } \\
\text { (current euro) }\end{array}$ & $\begin{array}{l}\text { Equivalent } \\
\text { household } \\
\text { expenditure } \\
\text { (current euro) }\end{array}$ & $\begin{array}{l}\text { Average } \\
\text { household } \\
\text { members }\end{array}$ & $\begin{array}{l}\text { Number of } \\
\text { households } \\
\text { in the HBS } \\
\text { sample }\end{array}$ & $\begin{array}{l}\text { Grossed } \\
\text { number of } \\
\text { households }\end{array}$ \\
\hline $\begin{array}{l}\text { Single person with } \\
\text { children }(\text { age }<18)\end{array}$ & 2,209 & 1,183 & 2.4 & 389 & 422,951 \\
\hline $\begin{array}{l}\text { Head of the family } \\
\text { retired }\end{array}$ & 1,983 & 1,252 & 2.0 & 9,373 & $8,841,900$ \\
\hline $\begin{array}{l}\text { Head of the family } \\
\text { unemployed }\end{array}$ & 1,853 & 985 & 2.8 & 523 & 533,547 \\
\hline Other households & 2,594 & 1,351 & 2.8 & 13,822 & $13,469,311$ \\
\hline Elderly households & 1,531 & 1,225 & 1.4 & 5,366 & $5,534,829$ \\
\hline Other households & 2,589 & 1,326 & 2.8 & 18,741 & $17,732,880$ \\
\hline Lowest $10 \%$ & 909 & 429 & 2.9 & 2,526 & $2,328,541$ \\
\hline Second decile & 1,267 & 618 & 2.8 & 2,472 & $2,325,176$ \\
\hline Third decile & 1,537 & 751 & 2.8 & 2,444 & $2,326,603$ \\
\hline Fourth decile & 1,757 & 884 & 2.7 & 2,491 & $2,326,978$ \\
\hline Fifth decile & 1,998 & 1,019 & 2.6 & 2,406 & $2,326,638$ \\
\hline Sixth decile & 2,216 & 1,167 & 2.5 & 2,408 & $2,327,465$ \\
\hline Seventh decile & 2,447 & 1,343 & 2.4 & 2,337 & $2,326,364$ \\
\hline Eighth decile & 2,763 & 1,582 & 2.2 & 2,342 & $2,328,638$ \\
\hline Ninth decile & 3,314 & 1,961 & 2.1 & 2,259 & $2,324,709$ \\
\hline Highest $10 \%$ & 5,169 & 3,266 & 2.0 & 2,422 & $2,326,597$ \\
\hline
\end{tabular}


All the selected groups spent less than the other households, with households whose head is unemployed and single parents showing major ${ }^{13}$ shortcomings. Thus, even if their limited sample size prevent from drawing quantitative conclusions, we thought that qualitative indication about possible inflation differentials for these groups could be of some interest for policy aims.

\section{Results}

\subsection{Weights' Effects}

Based on the considerations developed in Sects. 3.2 and 3.3, consumer price indexes were determined for each subpopulation considered using both the democratic and the plutocratic approaches. Chain price indexes ${ }^{14}$ for households sorted by equivalent expenditure decile are presented in Table 3.

Poorer households seem to have experienced higher inflation than richer ones, as shown both by plutocratic and democratic indexes. Chained price indexes (reference

Table 3 Plutocratic and democratic price indexes by families' decile (chained indexes reference base, values at December of each year)

\begin{tabular}{|c|c|c|c|c|c|c|c|c|c|c|}
\hline \multirow[t]{2}{*}{ Year } & \multicolumn{2}{|c|}{ Lowest $10 \%$} & \multicolumn{2}{|c|}{ Second decile } & \multicolumn{2}{|c|}{ Third decile } & \multicolumn{2}{|c|}{ Fourth decile } & \multicolumn{2}{|c|}{ Fifth decile } \\
\hline & $\mathrm{P}$ & D & $\mathrm{P}$ & $\mathrm{D}$ & $\mathrm{P}$ & $\mathrm{D}$ & $\mathrm{P}$ & $\mathrm{D}$ & $\mathrm{P}$ & $\mathrm{D}$ \\
\hline 2000 & 103.58 & 103.58 & 103.48 & 103.48 & 103.42 & 103.43 & 103.44 & 103.47 & 103.34 & 103.37 \\
\hline 2001 & 105.91 & 105.98 & 105.70 & 105.73 & 105.53 & 105.60 & 105.59 & 105.64 & 105.41 & 105.46 \\
\hline 2002 & 108.84 & 108.82 & 108.63 & 108.57 & 108.44 & 108.43 & 108.53 & 108.52 & 108.32 & 108.32 \\
\hline 2003 & 111.81 & 111.83 & 111.53 & 111.48 & 111.29 & 111.32 & 111.33 & 111.35 & 111.08 & 111.12 \\
\hline 2004 & 113.72 & 113.50 & 113.57 & 113.35 & 113.40 & 113.29 & 113.50 & 113.40 & 113.32 & 113.28 \\
\hline 2005 & 116.46 & 116.17 & 116.32 & 116.06 & 116.16 & 116.06 & 116.23 & 116.13 & 116.06 & 116.05 \\
\hline 2006 & 119.50 & 119.29 & 119.05 & 118.83 & 118.74 & 118.70 & 118.76 & 118.71 & 118.47 & 118.51 \\
\hline \multirow[t]{2}{*}{ Year } & \multicolumn{2}{|c|}{ Sixth decile } & \multicolumn{2}{|c|}{ Seventh decile } & \multicolumn{2}{|c|}{ Eighth decile } & \multicolumn{2}{|c|}{ Ninth decile } & \multicolumn{2}{|c|}{ Highest $10 \%$} \\
\hline & $\mathrm{P}$ & $\mathrm{D}$ & $\mathrm{P}$ & $\mathrm{D}$ & $\mathrm{P}$ & $\mathrm{D}$ & $\mathrm{P}$ & $\mathrm{D}$ & $\mathrm{P}$ & $\mathrm{D}$ \\
\hline 2000 & 103.28 & 103.31 & 103.23 & 103.26 & 103.18 & 103.22 & 103.13 & 103.16 & 102.70 & 102.79 \\
\hline 2001 & 105.34 & 105.38 & 105.27 & 105.28 & 105.18 & 105.19 & 105.14 & 105.16 & 104.67 & 104.78 \\
\hline 2002 & 108.26 & 108.26 & 108.17 & 108.14 & 108.08 & 108.07 & 107.97 & 108.01 & 107.24 & 107.36 \\
\hline 2003 & 110.95 & 111.00 & 110.85 & 110.87 & 110.72 & 110.75 & 110.56 & 110.65 & 109.53 & 109.76 \\
\hline 2004 & 113.23 & 113.19 & 113.17 & 113.12 & 113.07 & 113.07 & 112.97 & 113.04 & 112.16 & 112.38 \\
\hline 2005 & 115.88 & 115.86 & 115.84 & 115.83 & 115.64 & 115.68 & 115.44 & 115.57 & 114.65 & 114.89 \\
\hline 2006 & 118.27 & 118.29 & 118.15 & 118.19 & 117.97 & 118.05 & 117.77 & 117.91 & 116.74 & 117.05 \\
\hline
\end{tabular}

Note: (P) Plutocratic Index; (D) Democratic Index.

\footnotetext{
${ }^{13}$ Here, the use of an equivalence scale of Engel's type could have brought to an underestimation of older families' disadvantage versus the other targeted groups.

${ }^{14}$ Calculation base and reference base monthly indexes are available at request.
} 
base) display a regularly decreasing pattern by decile during the entire period 2000-2006. Moreover, indexes' differential between the poorest and the richest households slightly increases over time.

Analysis of trend inflation gives similar results, with families in the lowest tenth facing on the whole higher inflation rates, except for the periods August 2004September 2005 and April-August 2002 (Fig. 1).

It is interesting to note that periods of anti-poor price behaviour coincide with periods of higher gaps between official and perceived inflation in Italy, as reported by Del Giovane and Sabbatini (2006).

Inflation rates by subgroups defined by conditions of the head of the family (single parent or out-of-work ) do not significantly differ from the other households (Table 4), supporting the hypothesis that price dispersion within demographic group is so great to make across strata heterogeneity negligible (Garner et al., 1996).

This is also the case of older families that on average do not seem to have suffered faster inflation growth than the other households (Table 4). A slow-down of elderly' inflation rate of growth had been reported for the same period by Stewart (2008), caused primarily by changes in the relative inflation rates of medical care compared with overall inflation.

These data seem to suggest that income disposable for consumption is the only variable that could affect so much expenditures' patterns as to determine a grade of across-strata heterogeneity detectable even in presence of marked price heterogeneity within groups.

These differences in consumptions' profiles are synthesized in Fig. 2, reporting expenditures' shares for the 12 COICOP divisions, for the lowest and the highest deciles. The expenditures of "poorest" tenth per cent show a marked concentration

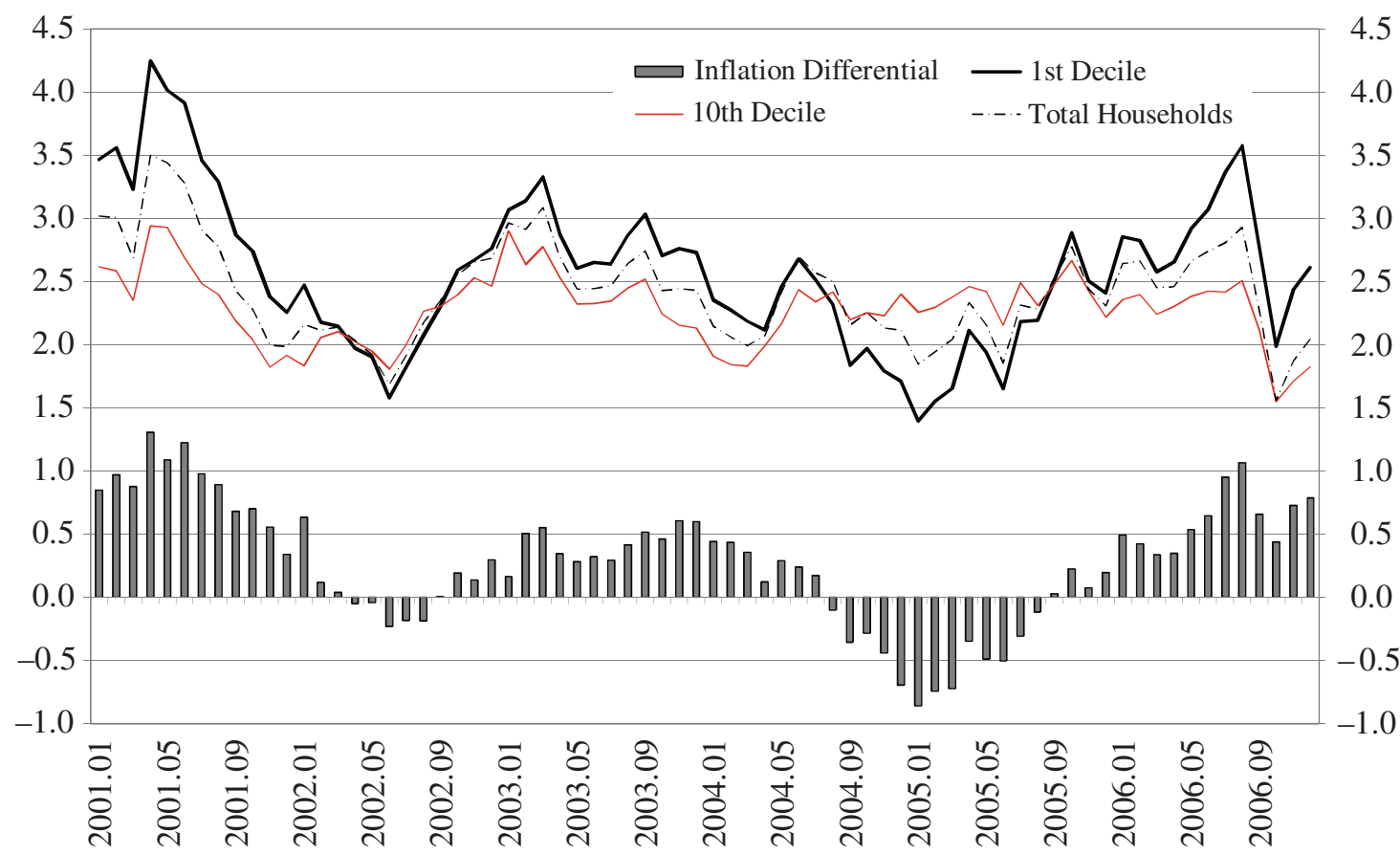

Fig. 1 Trend inflation by families' groups 
Table 4 Plutocratic price indexes by families' types (chained indexes reference base, values at December of each year)

\begin{tabular}{lllllll}
\hline & \multicolumn{5}{c}{ Single person } \\
Year & $\begin{array}{l}\text { Elderly } \\
\text { households }\end{array}$ & $\begin{array}{l}\text { Other } \\
\text { households }\end{array}$ & $\begin{array}{l}\text { with children } \\
\text { age < 18) }\end{array}$ & $\begin{array}{l}\text { Head of the } \\
\text { family retired }\end{array}$ & $\begin{array}{l}\text { Head of the family } \\
\text { unemployed }\end{array}$ & $\begin{array}{l}\text { Other } \\
\text { households }\end{array}$ \\
\hline 2000 & 103.34 & 103.12 & 103.03 & 103.22 & 102.92 & 103.12 \\
2001 & 105.55 & 105.15 & 105.00 & 105.35 & 104.90 & 105.14 \\
2002 & 107.93 & 108.04 & 107.82 & 108.02 & 107.77 & 108.03 \\
2003 & 110.78 & 110.62 & 110.58 & 110.73 & 110.57 & 110.60 \\
2004 & 112.33 & 113.09 & 113.06 & 112.76 & 112.99 & 113.09 \\
2005 & 114.91 & 115.70 & 115.55 & 115.41 & 115.63 & 115.67 \\
2006 & 117.39 & 118.05 & 117.98 & 117.80 & 118.15 & 118.02 \\
\hline
\end{tabular}

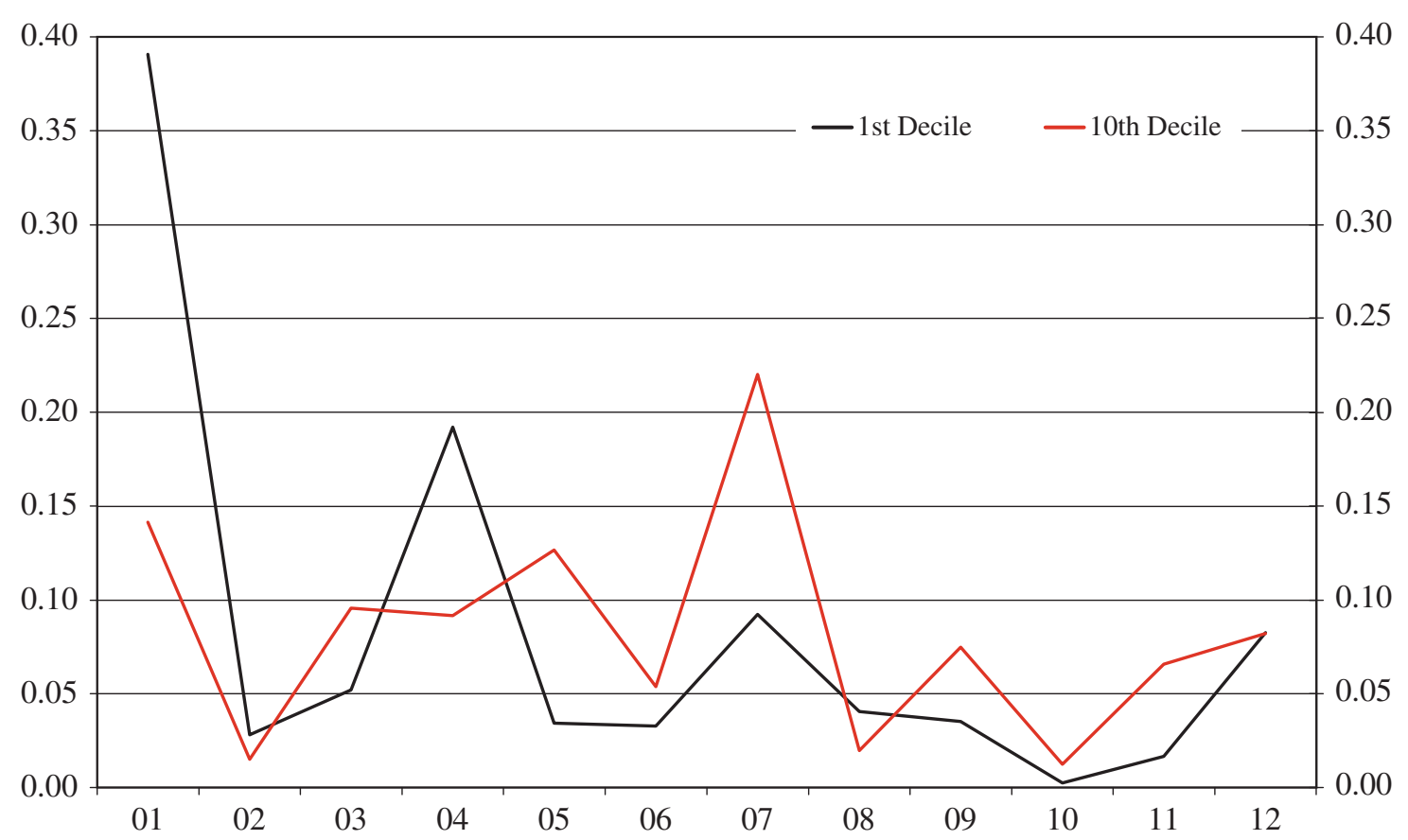

Fig. 2 Average consumptions' share lowest 10\% and highest 10\%. Note: (01) Food \& non alcoholic beverages; (02) Alcoholic beverages \& tobacco; (03) Clothing \& footwear; (04) Housing, water, electricity, gas \& other fuels; (05) Furnishing, household equipment \& routine household maintenance; (06) Health; (07) Transport; (08) Communication; (09) Recreation \& culture; (10) Education; (11) Restaurants \& hotels; (12) Miscellaneous goods \& services

in basic needs. Food (01), Housing (04) and Transport (07) account for more than two thirds of total expenditure, with the other shares ranging around $3 \%$.

"Richest" households show a different consumption profile. Food and Housing' expenditures markedly decrease, covering together the same share of Transport alone (doubled than the poorer's one). As expected, these consumers allocate not negligible shares of their total allowances to a wider set of commodities: Clothing (03) and Furnishing (05), but also Recreation \& culture (09) and Restaurants \& hotels (11). 
Even if at an aggregate (COICOP division) level, a significant temporal coincidence between greater-than-average trend inflation for Food, ${ }^{15}$ higher consumer price indexes for poor, and divergence between perceived and official inflation, can be observed.

\subsection{Effects of Aggregation System}

As shown in Table 3, plutocratic and democratic indexes do not markedly differ, unless in the extreme (first two and last two tenths) of the distribution by equivalent expenditure. For the entire population, plutocratic bias was negative, i.e. changes in prices hurt the poor more than the rich, during the entire period.

Applying decile-specific weights, for the lowest tenth of households differences between the two approaches should decrease. However, while until May 2004 plutocratic bias ranged around zero, afterwards the gap began to grow (Fig. 3).

As repeatedly pointed out by Kokoski (2003), since statistical significance of these results is not know, quantitative conclusions cannot be drawn, but in our opinion qualitative suggestions from these data may be of some interest. Namely,

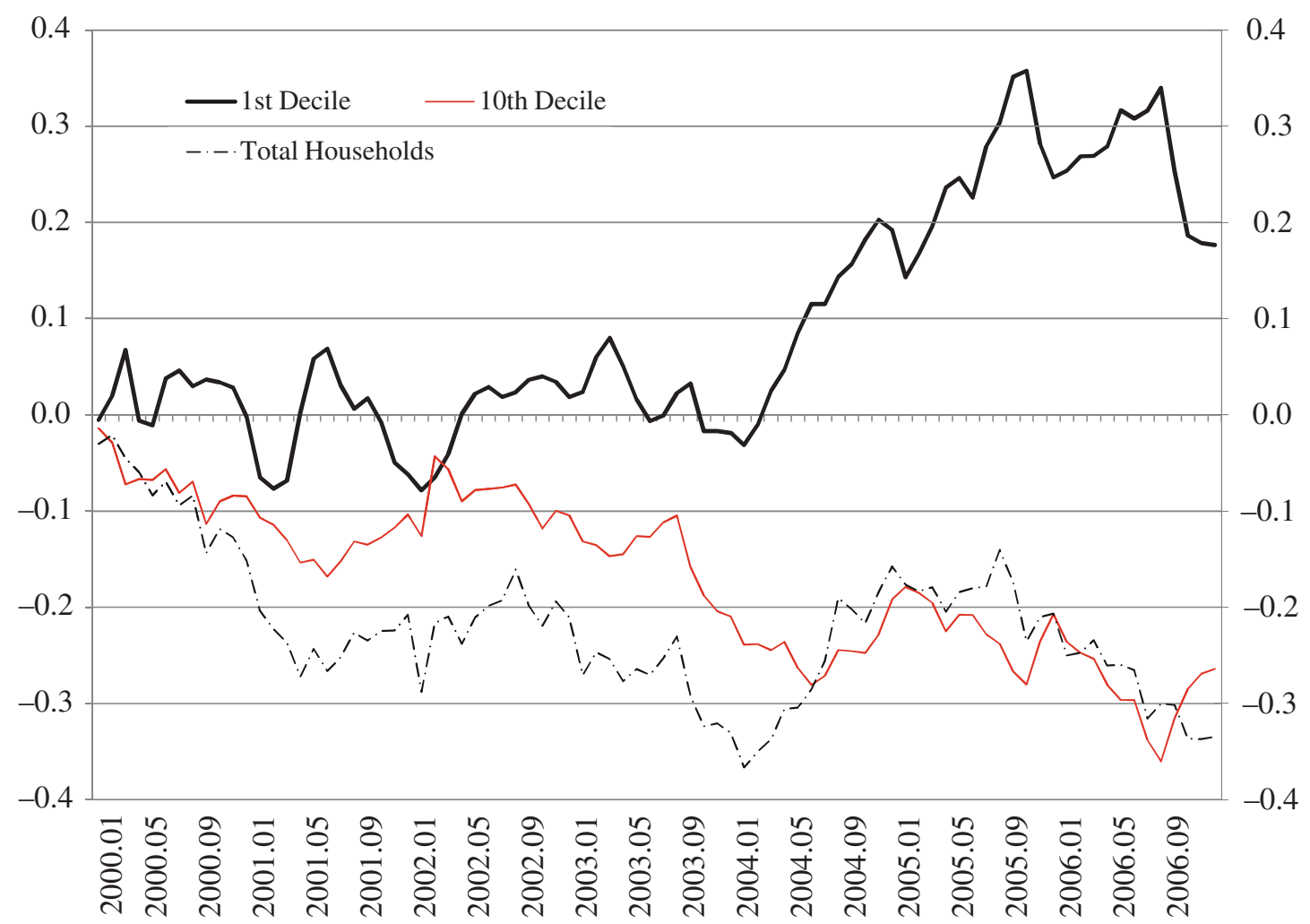

Fig. 3 Plutocratic bias lowest 10\%, highest $10 \%$ and total households

\footnotetext{
${ }^{15}$ In 2003 yearly inflation rate according to data published by ISTAT were 4.32 for Food vs an average of 2.50 .
} 
positive gaps at the end of the study-period might indicate an increase in relative prices of the more expensive items in the poorest' basket. By the way, in 2005-2006 inflation for Housing grew at about 5 point per cent per year, thus inverting the ratio with Food inflation rates as observed in previous years. This result melted with the increased inequality in the expenditure profiles of households within the group (as shown by the increasing positive gap).

On the other side, from June 2000 to May 2004 negative plutocratic gaps for the highest tenth of households are smaller - in absolute value - than for the entire population, since then they became nearly coincident, suggesting a flattening of "representative" household's weights on the richest' ones.

\subsection{Changing Basket}

The last issue in our empirical analysis was to investigate the effect of changes in the choice of goods and services in the reference basket on consumer price indexes.

To find out if inflation rates measured with a basket limited to basic needs could be more indicative of perceived inflation, we used (Carlucci \& Zelli, 1998) a basket of Necessities as expenditures for food and non-alcoholic beverages, electricity and household fuels; household cleaning products, communication charges.

Chained "Necessities" indexes are higher than CPI ones until the first half of 2004, with more pronounced gaps in 2003 (Fig. 4), for households in any decile ${ }^{16}$ of equivalised expenditures. This result comes in line with previous ones, supporting

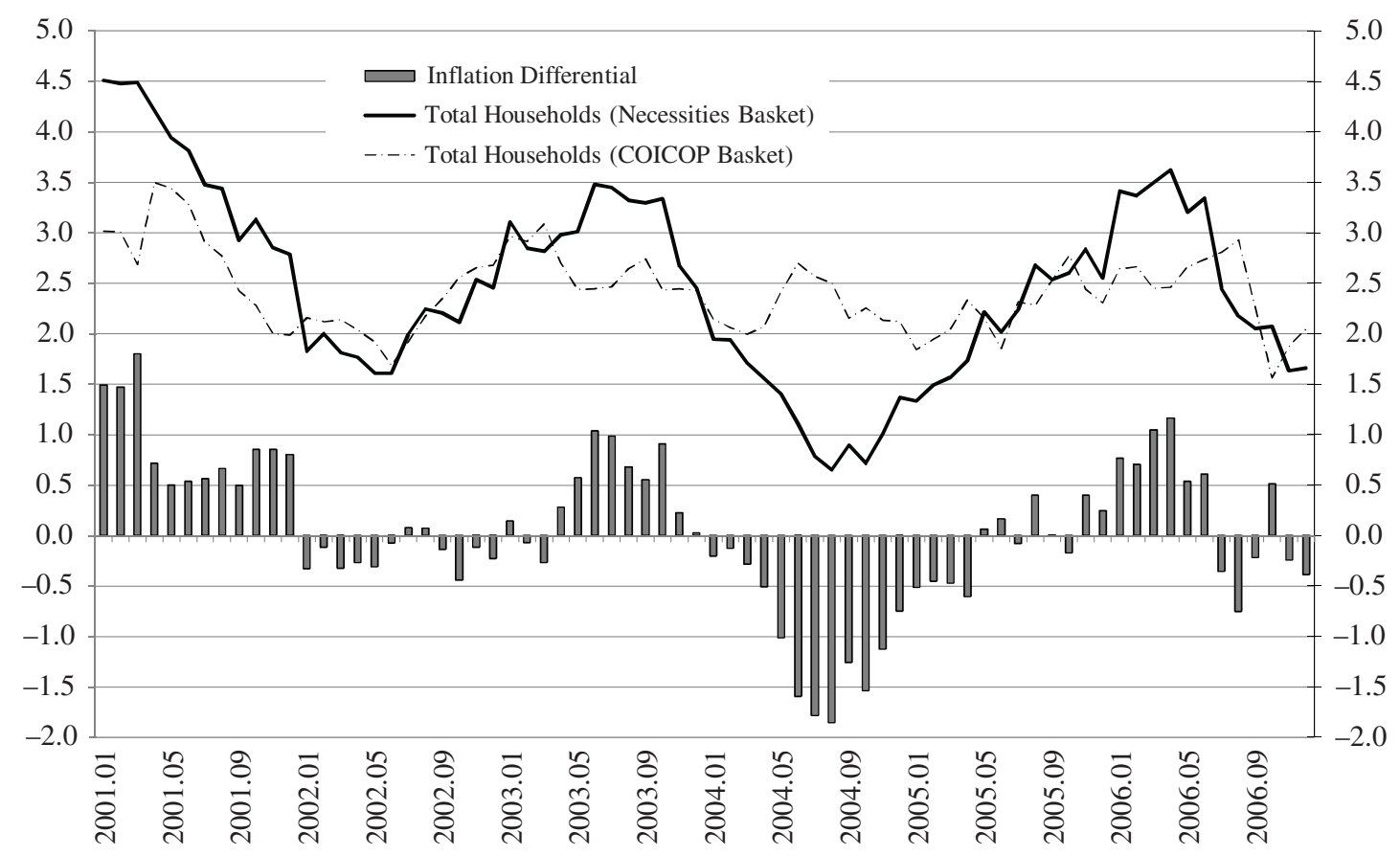

Fig. 4 Trend inflation with necessities and CPI basket

${ }^{16}$ Data available at request. 
the idea that higher prices' increases in frequently purchased items could contribute to determining gaps between official and perceived inflation.

\section{Final Remarks}

One discussed issue in economic debate is the adequacy of CPI in measuring inflation rates actually experienced by different households.

Thus, aim of this study was an exploratory analysis of the empirical evidence on households' specific inflation rates.

To do so, we defined a one-to-one match between $155 \mathrm{HBS}$ expenditure items and consumer price indexes, exhausting the entire reference domain of CPI listing.

We developed sub-indexes according to two criteria. Firstly, we broke down Italian families' by equivalised expenditure decile. Then, we selected households that were likely both to have specific consumption behavior and to be particularly sensitive to the loss of purchasing power: single person with dependent children; head of family workless through unemployment or economic inactivity; elderly.

Our results agree with previous studies in showing that the impact on inflation rates of differences in expenditure profiles across households grouped according to socio-demographic criteria is veiled by price heterogeneity within each group, whose extent could not be evaluated ${ }^{17}$ with official data. Only income disposable for consumption has been found to affect so much expenditures' patterns as to determine a detectable grade of across-strata heterogeneity. ${ }^{18}$

Then, we have analyzed the gap between inflation measured according to CPI and according to a democratic index, i.e. the plutocratic bias, positive or negative depending on whether prices behave in an anti-rich or an anti-poor manner. Moreover, we checked the effect of changes in the sample of goods and services, developing a Laspeyres price index for a basket of frequently purchased goods and services, defined as common "Necessities" of any type of households, related to daily basic personal needs and housing maintenance.

Evidence supporting the hypothesis of an anti-poor dynamic of relative prices following euro changeover also come from the findings of negative plutocratic bias and of values of the price indexes based on the Necessities basket greater then CPI ones, from early 2002 to the first half of 2004.

These results strongly suggest the need, for further research on inflation differentials by households' groups, to combine official data on CPI and households expenditures with prices' data detailed by outlet and brand/quality, collected by private statistical institutes.

Detailed analyses of this type are crucial for social policies' aims, helping in correctly assessing changes in the standard of living of different socio-economic clusters of households, at different territorial areas.

\footnotetext{
${ }^{17}$ For an analysis of price variations with private scanner data sets see "Price Dispersion: the Case of "Pasta"" in this volume.

${ }^{18}$ With poorer households having experienced higher inflation than richer ones.
} 


\section{References}

Adriani F., Marini G., \& Scaramozzino, P. (2009). The inflationary consequence of a currency changeover: Evidence from the Michelin Red Guide. Oxford Bulletin of Economics and Statistics, 71(1), 111-133.

Álvarez González, L., Cuadrado Salinas, P., Jareño Morago, J., \& Sánchez García, I. (2004). El impacto de la puesta en circulation del euro sobre los precios de consumo. Banco de Espana, Servicio de Estudios, Documentos ocasionales 0404. Retrieved 21 May, 2009, from http://www.bde.es

Antonides, G. (2008). How is perceived inflation related to actual price changes in the European Union? Journal of Economic Psychology, 29, 417-432.

Biggeri, L., \& Leoni, L., (2003, December 4-5). Families of consumer price indices for different purposes. In Joint Unece-ILO meeting on consumer price indices, Geneva.

BLS. (1997). The consumer price index. In BLS handbook of methods, Bulletin 2490 (updated 06/2007). Retrieved 21 May, 2009, from http://www.bls.gov/opub/hom/pdf/homch17.pdf.

Boskin, M. J., Dulberger, E., Gordon, R., Griliches, Z., \& Jorgenson, D. (1996, December 4). Toward a more accurate measure of the cost of living (Final Report to the Senate Finance Committee). Retrieved 21 May, 2009, form, http://www.ssa.gov/history/reports/boskinrpt.html

Brachinger, H. W. (2006). Euro or "Teuro"? The Euro-induced perceived inflation in Germany (Working Paper 5). Switzerland: Department of Quantitative Economics, University of Fribourg. Retrieved 21 May, 2009, from http://ideas.repec.org/p/fri/dqewps/wp0005.html

Carbonaro, G. (1985). Nota sulla scala di equivalenza. In Commissione di Indagine sulla povertà Primo rapporto sulla povertà in Italia. Roma: Presidenza del Consiglio dei Ministri.

Carlucci, M., \& Zelli, R. (1998). Expenditure patterns and equivalence scales. Paper presented to the 25th IARIW General Conference, Cambridge.

Deaton, A. (1998). Getting prices right: What should be done? Journal of Economic Perspectives, $12,37-46$.

Del Giovane, P., \& Sabbatini, R. (2006). Perceived and measured inflation after the launch of the euro: Explaining the gap in Italy. Giornale degli Economisti e Annali di Economia, 65(2), $155-192$.

Del Giovane, P., Fabiani, S., \& Sabbatini, R. (2008, January). What's behind "inflation perceptions"? A survey-based analysis of Italian consumers. TD No 655.

European Central Bank (2003, October). Recent developments in euro area inflation perceptions. Monthly Bulletin, 24-25.

European Central Bank (2007, May). Measured inflation and inflation perceptions in the euro area. Monthly Bulletin, 63-72.

Fluch, M., \& Stix, H. (2005). Perceived inflation in Austria - extent, explanations, effects. Monetary Policy \& the Economy, 3, 22-47.

Garner, T. I., Johnson, D. S., \& Kokoski, M. F. (1996, September). An experimental consumer price index for the poor. Monthly Labor Review, 119, 32-42.

Goni, E., Lopez, H., \& Servén, L. (2006, January). Getting real about inequality evidence from Brazil, Colombia, Mexico, and Peru (World Bank Policy Research Working Paper 3815). Retrieved 21 May, 2009, from http://econ.worldbank.org

Hill, R. J. (2004). Constructing price indexes across space and time: The case of the European Union. American Economic Review, 94(5), 1379-1410.

Istat (2007). Indicatori della dinamica dei prezzi al consumo per alcune tipologie di famiglie. Anni 2001-2006. Retrieved 21 May, 2009, from http://www.istat.it

Izquierdo, M., Ley, E., \& Ruiz-Castillo, J. (2003). The plutocratic gap in the CPI: Evidence from Spain. IMF Staff Papers 50(1). Retrieved 21 May, 2009, from http://www.imf.org

Jungermann, H., Brachinger, H. W., Belting, J., Grinberg, K., Zacharias, E. (2007). The Euro changeover and the factors influencing perceived inflation. Journal of Consumer Policy, 30(4), 405-419. 
Kokoski, M. F. (2003, December) Alternative consumer price index aggregations: Plutocratic and democratic approaches (BLS Working Paper 370). Retrieved 21 May, 2009, http://www.bls.gov

Kurri, S. (2006). Why does consumers' perceived inflation differ so much from actual inflation? Bank of Finland Bulletin, 3, 75-82. Retrieved 21 May, 2009, from http://www.bof.fi

Lyziak, T. (2009). Is inflation perceived by polish consumers driven by prices of frequently bought goods and services? Comparative Economic Studies, 51, 100-117.

Pollak, R. A. (1998). The consumer price index: A research agenda and three proposals. Journal of Economic Perspectives, 12(1), 69-78.

Ranyard, R., Missier, F. D., Bonini, N., Duxbury, D., \& Summers, B. (2008). Perceptions and expectations of price change and inflation. Journal of Economic Psychology, 29(1), 378-400.

Rao, V. (2000). Price heterogeneity and "real" inequality: A case study of prices and poverty in rural south India. Review of Income and Wealth, 46(2), 201-211.

Schultze, C. L., \& Mackie, C. (2002). At what price? Conceptualizing and measuring cost-of-living and price indexes. Panel on conceptual, measurement, and other statistical issues in developing cost-of-living indexes. Washington, DC: National Academy Press.

Silver, M., \& Heravi, S. (2007). Why elementary price index number formulas differ: Evidence on price dispersion. Journal of Econometrics, 140, 874-883.

Son, H. H., \& Kakwani, N. (2006). Measuring the impact of prices on inequality: With applications to Thailand and Korea. Journal of Economic Inequality, 4, 181-207.

Stewart, K. J. (2008, April). The experimental consumer price index for elderly Americans (CPIE): 1982-2007. Monthly Labor Review, 131, 19-24.

Wunder, C., Schwarze, J., Krug, G., \& Herzog, B. (2008). Welfare effects of the euro cash changeover. European Journal of Political Economy, 24, 571-586. 